\title{
Protective Effect of Andrographis paniculata against Thioacetamide Cytotoxicity in Liver and Kidney of Albino Rat
}

\author{
Patil R. $\mathbf{N}^{1}$, Salunkhe A. $\mathbf{J}^{2}$ \\ *Faculty of Zoology, P. G. Department of Zoology, Sadguru Gadage Maharaj College, Karad. 415124 (MS), India \\ ${ }^{2}$ P. G. Department of Zoology, Sadguru Gadage Maharaj College, Karad. 415124 (MS), India
}

\begin{abstract}
The present work has been designed to check hepatoprotective and renoprotective potency of aqueous extract of Andrographis paniculata. The whole plant extract of $A$. paniculata was used for treatment by using thioacetamide induced toxicity in liver and kidney of albino rat. Thioacetamide induces liver cirrhosis and nephrosclerosis. Thioacetamide induced toxicity in albino rat as manifested by the significant increase in total bilirubin, direct bilirubin, SGPT, SGOT and creatinine while significant decrease in liver protein and kidney protein. These results prove the potential hepatoprotective and renoprotective activity of A. paniculata extract.
\end{abstract}

Keywords: A. paniculata, liver, and kidney

\section{Introduction}

Liver cirrhosis is the damage of cells and their gradual replacement with scar tissue that damages blood flow through the liver producing hepatocyte death and loss of liver function [1].

The liver is an important organ concerned with various states of metabolic and physiologic homeostasis of the body [2]. It is involved in all biochemical pathways to growth, fight against disease and nutrient supply. The carbohydrate, protein and fat metabolism, detoxification, secretion of bile and storage of vitamins are the major functions of liver. Thus to sustain a healthy liver is an important factor for overall health and well-being [3].

The kidney is an essential organ that plays a dominant role in homeostasis by excreting the metabolic waste products and keeps necessary products depending on the needs of the body [4]. Kidney damage by various toxicants causes morphological with tubular or interstitial changes to nephropathy [5].

Thioacetamide (TAA) a potent hepatotoxin is used to control the decay of citrus fruits especially oranges there it is used as fungicide. TAA acts as a sulfur donor and used for various industrial and pharmaceutical application. It is also a carcinogenic [6] [7] [8] [9]. Thioacetamide induces cirrhosis pathological features of which are similar in many aspects to those of human liver disease caused by alcohol. It is one of numerous agents that cause structural and functional changes not only in liver but also in other tissues such as kidney, thymus, spleen and lungs [10].

In present medicine due to lack of defensive drugs in the treatment of liver diseases, medicinal plants are highly popular [11]. The long times history of using herbs in medicinal practice [12] [13]. In recent decades herbal medicine has received great attention because low costs and greater compatibility [14]. A number of plants have been shown to possess hepatoprotective property by improving antioxidant status [15].

A. paniculata also known commonly as "King of Bitter" is a member of plant family Acanthaceae. It is an herbaceous plant and used in traditional medicine. A. paniculata commonly known as Kalmegh is used as a bitter component in 26 Ayurvedic formulations. Modern pharmacological studies have demonstrated its cardioprotective, antithrombolytic, immunostimulant, antihyperglycemic, antimalarial and anti-inflammatory properties and so on [16].

In the present study the medicinal plant $A$. paniculata have been selected for hepatoprotective and renoprotective activity.

\section{Material}

\subsection{Animals}

Healthy adult Wistar rats (130 - 150gm) were procured from Hindustan Antibiotic Ltd, Pune and were acclimatized in laboratory condition for two weeks. They were fed with Amrut rat feed obtained from Pranav Agro Industries, Pvt. Ltd, Sangli and water ad libitum.

\section{Methods}

\subsection{Preparation of drugs}

TAA (Sigma Aldrich, Switzerland) was prepared freshly by dissolving in sterile distilled water and stirred until all crystals were dissolved. The TAA $200 \mathrm{mg} / \mathrm{kg}$ body weight was administered intraperitoneally (i.p.) to rats thrice a week for 8 weeks [17].

\subsection{Collection of plant material and extraction}

Fresh A. paniculata plant was obtained from Botanical garden of Krishna Mahavidyalaya Rethare BK. The plant 


\section{International Journal of Science and Research (IJSR) \\ ISSN (Online): 2319-7064 \\ Index Copernicus Value (2013): 6.14 | Impact Factor (2015): 6.391}

was authenticated by Dr. C. B. Salunkhe, Department of Botany, Krishna Mahavidyalaya Rethare BK. A voucher specimen (Collection No. 1719) has been kept in our laboratory for future reference.

\subsubsection{Preparation of extracts}

In a conical flask two hundred (200g) of powdered sample was mixed with $2000 \mathrm{ml}$ of distilled water. The conical flask shake severally covered overnight and stored at room temperature. The mixture was filtered by using Whatman filter paper number 1 . The filtrate was evaporated at $40^{\circ} \mathrm{C}$ upto complete dryness and forms chocolate coloured powder. This dried filtrate was scrapped, weighed and percentage yield was calculated. The dried filtrate was stored in a capped bottle and fresh solution was prepared at the time of experimentation [18].

\subsection{Experimental design}

The animals were divided into three groups each containing eight animals.

Group I: Control group of 3 to 5 months rat with either sex receiving intraperitoneal injection of distilled water for eight week.

Group II: Induced group were given i.p. injection of thioacetamide (TAA) $200 \mathrm{mg} / \mathrm{Kg}$ body weight three times a week for eight weeks [19].

Group III: Treated group were induced rats which were given A. paniculata extract orally at a dose $250 \mathrm{mg} / \mathrm{kg}$ doses three times a week for eight weeks.

\subsection{Blood sample collection}

At the end of experiment the animals were fasted for $12 \mathrm{hrs}$. weighed and sacrificed by cervical dislocation. Blood sample was directly collected from left ventricle and were allowed to clot at room temperature. After clotting the sample was centrifused and serum is obtained on top of tube. Serum was collected for further experiment.

\subsection{Biochemical method}

i) Total protein content was estimated by Lowry method [20] ii) Serum SGOT, SGPT, total and direct bilirubin was estimated by using commercial Kits.

iii) Blood creatinine was estimated by Jaffe's alkaline picrate method [21].

\section{Result}

The result obtained in the present investigation as shown in table No.1 and 2 and illustrated graphically in the fig.1, $2,3,4$. The activities of transaminases SGOT, SGPT, bilirubin and creatinine were significantly elevated in induced group when compared to the control group. On the other hand the increase in these parameters was prevented by treatment of animals with $A$. paniculata $250 \mathrm{mg} / \mathrm{kg}$ which resulted in nearly normalized levels of these parameters (table1).

Increased level of SGOT was noticed in thioacetamide induction group $(554.63 \pm 1.33)$ as compared to control group (102.13 \pm 1.23$)$. In treated group SGOT level was found decreased $(227.90 \pm 1.15)$. The SGPT level in control rat was $40.23 \pm 0.71$, in induction group was $96.47 \pm 0.84$ and in a treated group was $56.77 \pm 0.87$ (Fig.1).

The total bilirubin in control, induced and treated rat was 0.3 $\pm 0.08,0.8 \pm 0.08$ and $0.5 \pm 0.08$ respectively. The direct bilirubin was $0.13 \pm 0.05,0.5 \pm 0.08$ and $0.17 \pm 0.05 \mathrm{mg} / \mathrm{dl}$ in control, induced and treated rat respectively (Fig. 2).

Table 1: Effect of aqueous extract of $A$. paniculata on SGOT, SGPT, bilirubin and creatinine

\begin{tabular}{|c|c|c|c|}
\hline & \begin{tabular}{|c|} 
Control \\
\end{tabular} & Induced & Treated \\
\hline SGOT U/L & $102.13 \pm 1.23$ & $554.63 \pm 1.33$ & $227.90 \pm 1.15$ \\
\hline SGPT U/L & $40.23 \pm 0.71$ & $96.47 \pm 0.84$ & $56.77 \pm 0.87$ \\
\hline Bilirubin (Total) mg/dl & $0.3 \pm 0.08$ & $0.8 \pm 0.08$ & $0.5 \pm 0.08$ \\
\hline Bilirubin(Direct) mg/dl & $0.13 \pm 0.05$ & $0.5 \pm 0.08$ & $0.17 \pm 0.05$ \\
\hline Creatinine Mg/lit & $14.46 \pm 0.69$ & $36.38 \pm 0.41$ & $13.94 \pm 0.81$ \\
\hline
\end{tabular}

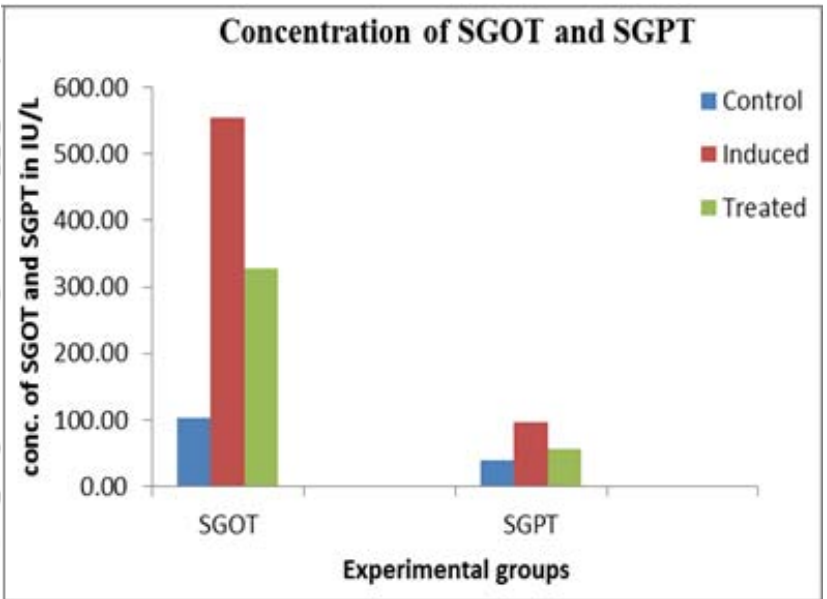

Figure 1: Variations in conc. of SGOT and SGPT of different group

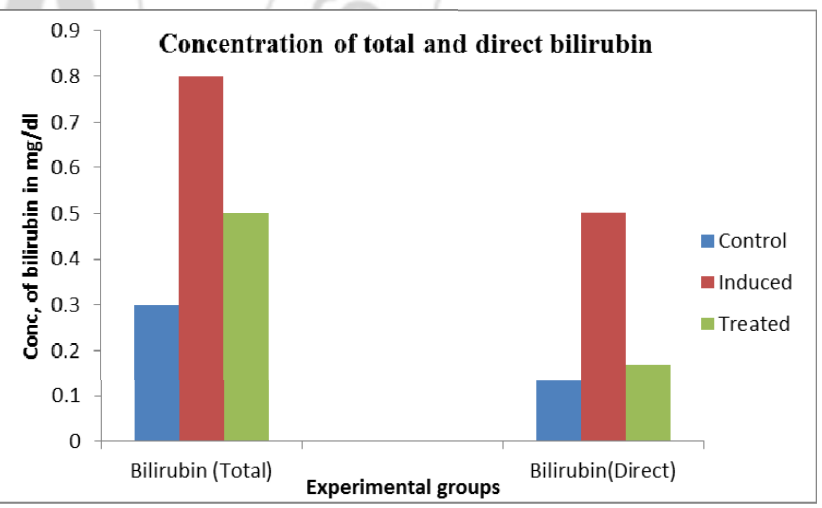

Figure 2: Change in conc. of total and direct bilirubin of different group of rats 


\section{International Journal of Science and Research (IJSR) \\ ISSN (Online): 2319-7064}

Index Copernicus Value (2013): 6.14 | Impact Factor (2015): 6.391

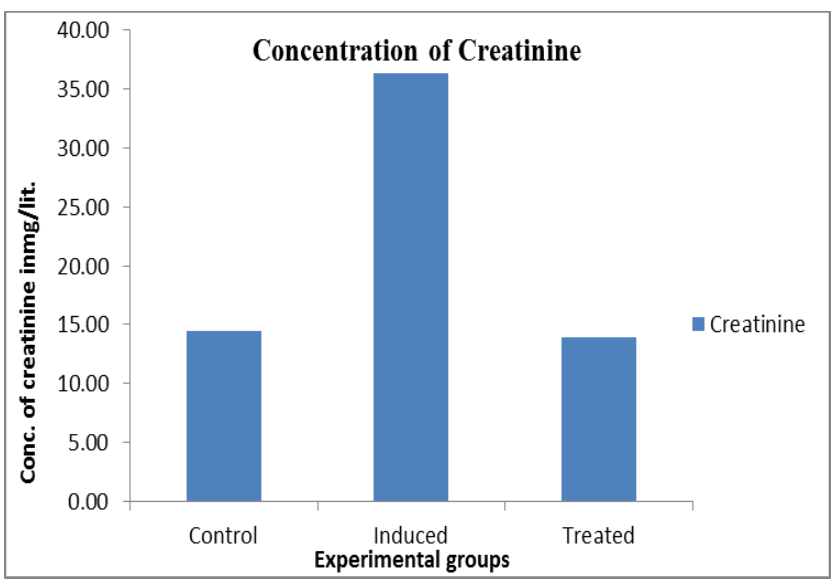

Figure 3: Conc. of creatinine in different group

Table 2: Effect of aqueous extract of $A$. paniculata on Protein in liver and kidney.

\begin{tabular}{|c|c|c|c|}
\hline & Control & Induced & Treated \\
\hline $\begin{array}{c}\text { Protein (Liver) } \\
\text { mg/gm }\end{array}$ & $206.6 \pm 68.69$ & $117.33 \pm 7.54$ & $186.67 \pm 43.49$ \\
\hline $\begin{array}{c}\text { Protein (Kidney) } \\
\text { mg/gm }\end{array}$ & $20.67 \pm 52.67$ & $125.33 \pm 15.08$ & $149.33 \pm 19.96$ \\
\hline
\end{tabular}

Each value is the mean of 8 individual determinations \pm indicates SD

The creatinine in control group is $14.46 \pm 0.69 \mathrm{mg} / \mathrm{lit}$. whereas in induced group it is increased to $36.38 \pm 0.41$ $\mathrm{mg} / \mathrm{lit}$. and in a treated group will be $13.94 \pm 0.81$ (Fig. 3 ).

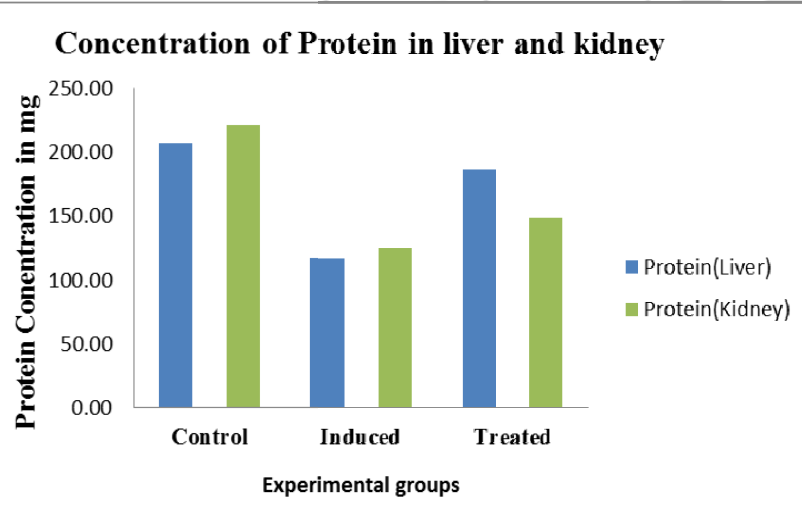

Figure 4: Change in conc. of total proteins in liver and kidney of different groups albino rat.

The total protein conc. is decreased in induced group i.e. in liver and kidney (117.33 \pm 7.54 and $125.33 \pm 15.08 \mathrm{mg} / \mathrm{gm}$.) as compared to normal rat (206.67 \pm 68.69 and $220.67 \pm$ $52.67 \mathrm{mg} / \mathrm{gm})$. The treated group shows increased protein conc. in liver and kidney i.e. $186.67 \pm 43.49$ and $149.33 \pm$ $19.96 \mathrm{mg} / \mathrm{gm}$ as compared to induced group (Fig.4).

\section{Discussion}

Liver shows many important functions one of these is a detoxification of xenobiotics and toxin [22]. Some industrial and environmental toxicants and other drugs can cause renal damage due to activation of highly reactive free radicals
[23]. Thioacetamide is a hepatotoxic and produce hepatic necrosis. On metabolism thioacetamide produce free radicals resulting in oxidative stress and induces apoptasis of hepatocytes [24]. On long term taken thioacetamide causes cirrhosis in rats. Thioacetamide induces centrolobular hepatic necrosis, hepatocellular carcinoma, liver cirrhosis and injury to the terminal portion of the proximal renal tubule [25].

In the present study thioacetamide administered $200 \mathrm{mg} / \mathrm{Kg}$ dose i.p. for 8 week resulted in increase in some liver biomarkers. These observations are similar to those of [26] [27] [28] [29] who have used thioacetamide to induce liver cirrhosis. The TAA is a potent hepatotoxin, it is processed by Cytochrome 450 enzyme in liver and converted into toxic substance TAAS- oxide and TAAS - dioxide by oxidative chain reaction [30]. In chronic condition TAA intoxication, considerable liver fibrosis and prominent regenerative nodule development are associated with portal hypertension and hyperdynamic circulation individuals of liver cirrhosis [31]. This is evidenced by variations in the level of ALT, AST, and Bilirubin in plasma.

The SGOT is a mitochondrial enzyme which is increased in liver damage. Some important liver biomarkers such as SGOT, SGPT, bilirubin, ALP, total proteins etc. which evaluate liver toxicity and its amounts of leak into blood stream indicate severity of hepatic damage [32]. Bilirubin is one of the most useful clinical markers to indicate to the severity of necrosis and its increase is a quantity of binding, conjugation and excretory capacity of hepatocytes. Creatinine, a non-protein waste product is freely filtered by the kidney. The serum creatinine concentration is the most commonly used parameter of the kidney function. The level of creatinine in the blood rises if kidney is not function properly. Current research has focused on alternative approaches to synthetic pharmacology, which rely on natural products. It target on medicinal plants which shows curative effect on diseases of the liver or other organ [33].

Whole parts of $A$. paniculata plant have many benefits by means of liver and kidney diseases such as it decrease in SGPT levels in different liver injury models such as ethanol [34], $\mathrm{CCl}_{4}$ [35] [36] and acetaminophen induced liver injury [37] [38]. The elevated level of these hepatic marker enzymes such as SGPT, SGPT in the induced group which is reduced in treated group. The creatinine level which was increased in induced group was decreased or becoming nearly equal to the value of control group in a treated group.

The protein concentration in liver and kidney in a induced group is decreased and in a treated group protein concentration is increased [39] because induced group is treated by aqueous extract of $A$. paniculata $250 \mathrm{mg} / \mathrm{kg}$. Collectively, from the above results suggest that $A$. paniculata at the dose of $250 \mathrm{mg} / \mathrm{Kg}$ body weight is recovering since it has improved activity on protein levels apart from other beneficial features. It contains andrographolides, alkaloids, flavonoids, phenolic compounds steroids and saponins. 


\section{International Journal of Science and Research (IJSR) \\ ISSN (Online): 2319-7064 \\ Index Copernicus Value (2013): 6.14 | Impact Factor (2015): 6.391}

\section{Conclusion}

The aqueous extracts of Andrographis paniculata have shown hepatoprotective and renoprotective effect against TAA induced hepatotoxicity and renotoxicity in rats in reducing serum bilirubin, SGOT, SGPT and creatinine levels. It also found that total proteins in liver and kidney are increased by A. paniculata.

\section{Acknowledgement}

The author is grateful to Principal and Head, P.G. Dept. of Zoology, S. G. M. College, Karad, for providing the necessary facilities during present work.

\section{References}

[1] Wang, S. and Nagrath, D. (2010). Liver Tissue Engineering. Biomaterial for Tissue Engineering Applications: A review of the Past and Future Trends, 14:389.

[2] Verma, N. and Khosa, R. L. (2010). Hepatoprotective activity of leaves of Zanthoxylum aramatum DC in $\mathrm{CCL}_{4}$ induced hepatotoxicity in rats. Indian journal of biochemistry and biophysics 47:124-127.

[3] Rajib, A., Monirul, K. M., Musaddik, A. and Haque, E. [2009]. Hepatoprotective activity of methanol extract of some medicinal plants against carbon tetrachloride induced hepatotoxicity in albino rats. Global journal of pharmacology; 3(3):116-122.

[4] Hall, J. E. Text Book of Medical Physiology (2011). 12 ed. Philadelphia:Saunders Elsevier ..p 307-326.

[5] Silva, F. G. [2004]. Chemical- induced nephropathy. A review of the renal tubulointestitial lesions in humans. Toxicol Paththol. 32(2):71-84.

[6] Chilakapati, J., Shankar, K., Korrapati, M.C., Hill K.C. and Mehendale, H.M. (2005)."Saturation Toxicokinetics of Thioacetamide: Role in Initiation of Liver Injury," Drug Metabolism and Disposition, Vol. 33, No. 12, 2005, pp. 1877-1885.14.

[7] Childs, J.F.L.and Siegler, E.A.. (1945). Uses of thioacetamide in agriculture. Science (Wash DC,)102:68-72.

[8] Fitzhugh, O.G and Nelson, A.A.,(1948). Liver tumors in rats fed thiourea or thioacetamide. Science. 108: 626628.

[9] Lee, J. W., Shin, K. D., Lee, M. Kim, E. J., Han, S. S. and Han, M. Y. (2003)."Role of Metabolism by FlavinContaining Monooxygenase in Thioacetamide-Induced Immunosup- pression," Toxicology Letters, Vol. 136, No. 3, 2003, pp. 163-172.

[10] Sirag, H. M. (2007). Biochemical studies on thioacetamide toxicity in male albino rats and the role of tomato juice as an antioxidant. Mansoura J Forensic Med Clin Toxicol. 15: 90-114.

[11] Mohammed , A., Alshawsh, M., Ameen A., Salmah Ismail and Zahra, A. (2009). Amin: Hepatoprotective effects of Orthosiphon stamineus extract on Thioacetamide-induced liver cirrhosis in rats. Malaysia Grant, 182, 1- 14

[12] Azadbakht, M. Ziai, H. Abdollahi, F. Shabankhani, B. (2003). Effect of essential oils of Artemisia Aucheri
Bioss., Zataria Multiflora Boiss and Myrtus Communis L. on Trichomonas Vaginalis. Iran J Pharm Res, 2: 3535.

[13] Kavita, V. and Sanjay, G. (2002) .Herbal medicines for sexually transmitted diseases and AIDS. JEthnopharmacol, 80: 49-66.

[14] Azadbakht, M. Ziai. H., Abdollahi, F. Shabankhani B. (2003). Effect of essential oils of Artemisia Aucheri Bioss., Zataria Multiflora Boiss and Myrtus Communis L. on Trichomonas Vaginalis. Iran J Pharm Res, 2: 3535.

[15] Vinothkumar, P.,Sivaraj, A., Devi, K. and Senthilkumar B. (2010). Hepatoprotective and antioxidant properties of aqueous rhizome extracts of Picrorhiza kurroa on CCl4 induced liver toxicity in albino rats. J Pharmacy. Res2010;3 (6):1280-1282.

[16] Ojha, S.K., Nandave, M., Kumari, S. and Arya, D. S. (2009). Antioxidant activity of AP in Ischemic Myocardium of Rats. Global Journal of Pharmacology .3(3):154-157.

[17] Alshawsh, M. A., Abdulla, M. A., Ismail, S., Amin, Z. A. (2011). Hepatoprotective effects of orthosiphon stamineus extract on thioacetamide-induced liver cirrhosis in rats. Evidence-Based Complementary and Alternative Medicine. 2011;2011:6 pages.

[18] Nasir, A. Abubakar, M.G. Shehu, R.A. Aliyu, U. and Toge, B.K.(2013). "Hepatoprotective Effect of the Aqueous Leaf Extract of Andrographis paniculata Nees Against Carbon Tetrachloride - Induced Hepatotoxicity in Rats". Nigerian Journal of Basic and Applied Science. 21(1): 45-54.

[19] Salama, S. M., Abdulla, M. A., AlRashdi, A. S., Ismail, A. Alkiyumi, S. S. and Golbabapour, S. (2013). "Hepatoprotective effect of ethanolic extract of Curcuma longa on thioacetamide induced liver cirrhosis in rats". BMC Complementary and Alternative Medicine . 13:56.

[20] Lowry, O. H., Rosebrough, N. J., Farr, A. L., Randall, R. J. (1951). Protein measurement with the Folin phenol reagent. J Bio Chem 193: 265-275.

[21] Spierto, F. W., MacNeil, M. L. and Burtis, C. A. (1979). The effect of temperature and wavelength on the measurement of creatinine with the Jaffe procedure. Clin Biochem 12(1): 18 - 21.

[22] Mitra, S. K. (1998). Protective effect of HD-03, a herbal formulatin, against various hepatotoxic agents in rats. J. Ethnopharmacol. 63, 181-186.

[23] Olagunju, J., Adeneye, A., Fagbohunka, B., Bisuga, N., Ketiku, A., Benebo, A., Olufowobi, O., Adeoye, A., Alimi, M., Adeleke, A. (2009). Nephroprotective activities of the aqueous seed extract of Carica papaya Linn. in carbon tetrachloride induced renal injured Wistar rats: a dose-and time-dependent study. Biol Med 2009, 1(1):11-19.

[24] Sun, F., Hayami, S., Ogiri, Y. (2000). Evaluation of oxidative stress based on lipid hydroperoxide, vitamin c and vitamin e during apoptosis and necrosis caused by thioacetamide in rat liver. Biochimica et Biophysica Acta. 1500(2):181-185.

[25] Edward, A. and Baker, E. (1974). Nonhepatic Thioacetamide Injury. The morphologic Features of proximal renal tubular injury. Am J Pathol. 74(3):576590. [3] Rajib, A., Monirul, K. M., Musaddik, A. and 


\section{International Journal of Science and Research (IJSR) \\ ISSN (Online): 2319-7064 \\ Index Copernicus Value (2013): 6.14 | Impact Factor (2015): 6.391}

Haque, E. [2009]. Hepatoprotective activity of methanol extract of some medicinal plants against carbon tetrachloride induced hepatotoxicity in albino rats. Global journal of pharmacology; 3(3):116-122.

[26] Alkiyumi, S. S., Abdulla, M. A., Alrashdi, A. S., Salama, S. M. Abdelwaheb, S. I. and Hadi, A. H.(2012). Impomia aquatic extract shows protective action against thioacetamide induced hepatotoxicity. Molecules 17, $6146-6155$.

[27] Salama, S. M., Mehmet, B., AlRashdi, A. S. and Abdulla, M. A. (2012). Efficacy of Boesenbergia rotunda treatment against thioacetamide induced liver cirrhosis in rats. Evidence Based Complementary and Alternative Medicine. 1-12.

[28] Zahra, A. A.,. Mehmet, B., Mohammed A. A., Hapipah M. A., Hadi H. A., and Mahmood A A. (2012). "Protective Role of Phyllanthus niruri Extract against Thioacetamide-Induced Liver Cirrhosis in Rat Model”. Evid Based Complement Alternat Med. 241583.

[29] Kadir, F. A., Othman, F., Abdulla, M. A., Hussan, F., Hassandarvish, P. (2011). Effect of Tinospora crispa on thioacetamide-induced liver cirrhosis in rats. Indian $\mathrm{J}$ Pharmacol .43(1):64.

[30] Kadir, F. A., Othman, F., Abdulla, M. A., Hussan, F., Hassandarvish, P. (2011). Effect of Tinospora crispa on thioacetamide-induced liver cirrhosis in rats. Indian $\mathrm{J}$ Pharmacol .43(1):64.

[31] Kanagasabapathy,G., Malek, N. A., Kuppusamy, U. R. and Vikineswary, S. (2011). "Chemical composition and antioxidant properties of extracts of fresh fruiting bodies of Pleurotus sajor-caju (Fr.)singer," Jounal of Agricultural and Food Chemistry. vol. 59.no. 6, pp, 2618- 2626.

[32] Hori, N. Okanoue, T. Sawa, Y. Mori, T. and Kashima, K. (1993). Hemodynamic characterization in experimental liver cirrhosis induced by thioacetamide administration. Digestive diseases and sciences. 38(12):2195-2202.

[33] Khanna, D., Sethi, G. and Ahn, K. S. (2007). "Natural products as a gold mine for arthritis treatment"Current Opinion in Pharmacology, vol.7, no.3,pp. 344-351

[34] Singha, P. K., Roy, S. and Dey, S. (2007). Protective activity of andrographolides and arabinogalactan proteins from Andrographis paniculata Nees. Against ethanol induced toxicity in mice. J Ethnopharmacol. 111:13-21.

[35] Akowuah, G. A., Zhari, I., Mariam, A. and Yam, M. F. (2009). Absorption of andrographolides from Andrographis paniculata and its effect on $\mathrm{CCl}_{4}$ induced oxidative stress in rats. Food Chem Toxicol.47:23212326.

[36] Ye, J. F., Zhu, R. B., Xiong, X. W., Wang, L. X., Su, and Luo. (2011). Protective mechanism of andrographolides against carbon tetrachloride induced acute liver injury in mice. Biol pharm Bull. 34:16661670.

[37] Shukla, B.P., Visen, K.,Patnaik G. K.. and Dhawan, B. N. (1992). Choleretic effect of andrographolides in rats and guinea pigs. Planta Med. 58:146-149.

[38] Visen PK, Shukla B, Patnaik GK, Dhawan BN. Andrographolie protect rat hepatocyte against paracetamol induced damge. J Ethnopharmacol 1993;40:131-136.
[39] Akram E, Pejman M, Maryam B, Jalaj Z Hepatoprotective activity of Cinnamon ethanolic extract against $\mathrm{CCl}_{4}$ induced liver injury in rats. EXCLI J 2012:11:495-507. 